\title{
TINJAUAN TEORI PERENCANAAN DALAM PELAKSANAAN PROGRAM PEMANFAATAN DANA DESA
}

\author{
Yeni Nur Afifah \\ Magister Perencanaan Kota dan Daerah, Fakultas Teknik \\ Universitas Gadjah Mada Yogyakarta \\ yeninurafifah92@gmail.com
}

\begin{abstract}
The Law Number 6 of 2014 has raised the Village Fund and since the beginning has been disbursed continues to be spotlight considering the size is quite large and always increases every year. Considering the programs carried out through the use of Village Funds are actually development programs, it should have been included in planning studies so that the objectives achieved can be realized optimally. This reseearch aimed to examine implementation's suitability of the Village Fund utilization program with general planning theory. The approach taken in this study is a deductive approach, started from theory and literature review and then become a reference in studying the object of research. The analysis method used descriptive qualitative method with data obtained from in-depth interviews and document studies with purposive sampling sampling technique which is continued to snow-ball sampling. From 2015 to 2018, Jatiroto Village has produced six development products from the Village Fund utilization program, namely village roads, road grafts, agricultural roads, revitalization of volleyball courts, construction of village shops, and equity participation in BUMDes. Based on the research conducted, it turns out that the programs being run are not in accordance with general planning theory.
\end{abstract}

Keyword: development, planning, village fund

Abstraksi. Undang-undang Nomor 6 tahun 2014 telah memunculkan Dana Desa dan sejak awal digelontorkan terus menjadi sorotan mengingat nominalnya yang cukup besar dan selalu meningkat setiap tahunnya. Mengingat program-program yang terselenggara melalui pemanfaatan Dana Desa sejatinya merupakan program pembangunan, sudah seyogyanya jika di dalamnya juga melibatkan kajian perencanaan agar tujuan-tujuan yang hendak dicapai dapat terwujud secara optimal. Penelitian ini bertujuan mengkaji kesesuaian pelaksanaan program pemanfaatan Dana Desa dengan teori perencanaan secara umum. Pendekatan yang dilakukan pada penelitian ini adalah pendekatan deduktif yang bermula dari teori dan kajian pustaka dan kemudian dijadikan acuan dalam mengkaji obyek penelitian. Adapaun metode analisisnya menggunakan metode deskriptif kualitatif dengan data yang diperoleh dari wawancara mendalam dan studi dokumen dengan teknik pengambilan sampel snow-ball sampling. Terhitung sejak tahun 2015 hingga 2018, desa Jatiroto telah menghasilkan enam produk pembangunan dari program pemanfaatan Dana Desa, yakni jalan desa, talud jalan, jalan pertanian, revitalisasi lapangan voli, pembangunan kios desa, dan penyertaan modal BUMDes. Berdasarkan penelitian yang dilakukan, ternyata program-program yang dijalankan tersebut tidak sesuai dengan teori perencanaan secara umum.

Kata kunci: dana desa, pembangunan, perencanaan 


\section{PENDAHULUAN}

Adanya Undang-Undang Nomor 6 tahun 2014 tentang Desa telah menjadikan desa sebagai ujung tombak salah satu upaya memeratakan pembangunan dan peningkatan kesejahteraan masyarakat di Indonesia. Sebagaimana dijelaskan pada Pasal 4 huruf $\mathrm{b}$, undang-undang ini menjadikan desa memiliki status yang jelas dan kepastian hukum dalam sistem ketatanegaraan.

Salah satu kebijakan yang muncul dari undang-undang ini adalah Dana Desa, yang bersumber dari Anggaran Pendapatan dan Belanja Negara (APBN) yang setiap tahunnya disalurkan ke desadesa untuk dikelola pemerintah desa dalam rangka memajukan daerahnya masing-masing. Dalam undang-undang tersebut juga dijelaskan bahwa desa memiliki kewenangan dalam menentukan pemanfaatnya, meski terdapat programprogram prioritas yang diamanatkan pemerintah pusat.

Sejak awal digelontorkan, Dana Desa ini terus menjadi sorotan mengingat nominalnya yang cukup besar dan selalu meningkat setiap tahunnya. Pada tahun 2015, pemerintah telah menganggarkan Rp20.7 triliun untuk Dana Desa dan masing-masing desa rata-rata memperoleh Rp280 juta. Setahun berikutnya, anggaran tersebut meningkat lebih dari dua kali lipat hingga Rp46.98 triliun, tahun 2017 menjadi Rp60 triliun, dan 2018 kemarin setiap desa rata-rata mendapat Rp1.4 miliar dengan total Rp120 triliun.

Dalam Peraturan Pemerintah nomor 60 tahun 2014, terutama pada Pasal 20, penggunaan Dna Desa mengacu pada Rencana Pembangunan Jangka Menengah Desa (RPJMDes) dan
Rencana Kerja Pemerintah Desa (RKP Desa). Penetapan prioritasnya dilakukan setelah berkoordinasi dengan menteri yang bertanggungjawab dalam urusan pemerintaan bidang perencanaan pembangunan nasional dan menteri teknis atau pimpinan lembaga pemerintah non-kementerian. Selanjutnya, pihakpihak tersebut akan berkolaborasi membuat pedoman umum kegiatan yang didanai dari Dana Desa berdasarkan prioritas yang ditentukan. Selain itu, bupati atau walikota juga dapat membuat pedoman teknis kegiatan dengan berlandas pada pedoman umum kegiatan tersebut.

Terkait masalah pembangunan, Coraile B dan Louise G. White (1982) mengemukakan bahwa pembangunan merupakan peningkatan kapasitas seseorang untuk mempengaruhi masa depannya, program-program yang dibuat tidak hanya membuahkan perubahan fisik konkrit melainkan melibatkan masyarakat untuk memberikan pendapat dn masukan terhadap perubahan yang terjadi. Dari definisi tersebut, pembangunan tidak hanya diukur dari modernisasi gaya atau teknologi, tetapi juga dari potensi daerah dan pemanfaatannya untuk mencapai pertumbuhan ekonomi. Karena itulah pembangunan memiliki beberapa prasyarat, yakni kapasitas, keadilan, peningkatan kekuasaan dan wewenang, dan berkelanjutan.

Heiling dkk (2005) mengungkapkan bahwa dalam konsep pembangunan lokal, pemerintah lokal merupakan pemegang kekuasaan tertinggi dalam melaksanakan program pembangunan, termasuk perencanaan, pengambilan keputusan, penegakan aturan, dan proses akuntabilitasnya. Kehadiran Dana Desa ini memberikan peluang dan fasilitas 
lebih besar bagi desa untuk melaksanakan pembangunan lokal yang nantinya diharapkan dapat membantu desa menjadi lebih mandiri dan maju.

Sebagaimana disinggung sekilas sebelumnya, segala kegiatan pembangunan tidak terlepas dari perencanaan. Menurut Turner dan Hulme (1997), perencanaan merupakan proses modernisasi perubahan menyeluruh dari masyarakat tradisional atau pra-modern ke bentuk penguasaan teknologi dan perubahan organisasi sosial masyarakat dengan meningkatkan kesejahteraan ekonomi dan stabilisasi politik sebagaimana yang terjadi di dunia barat. Sementara itu, Bryant dan White (1982) menganggap perencanaan sebagai upaya peningkatan kapasitas untuk mempengaruhi masa depan dengan beberapa implikasi berupa pemberian perhatian terhadap kapasitas, segala yang perlu dilakukan untuk mengembangkan kemampuan, dan tenaga untuk membuat perubahan yang mencakup keadilan, mengingat perhatian yang berat sebelah ke kelompok tertentu dapat memecah belah masyarakat sehingga bisa mengurangi kapasitasnya, dan penumbuhan kuasa dan wewenang tertentu, mereka akan menerima manfaat pembangunan.

Proses perencanaan berdasarkan pendapat dari Berry (1993) dalam Mahi dan Trigunarso (2017) meliputi tujuh tahap berikut.

1. Diagnosis masalah

2. Perumusan tujuan

3. Proyeksi dan perkiraan

4. Pengembangan alternatif

5. Analisis kelayakan

6. Evaluasi

7. Implementasi
Mengingat program-program yang terselenggara melalui pemanfaatan Dana Desa sejatinya merupakan program pembangunan, sudah seyogyanya jika di dalamnya juga melibatkan kajian perencanaan agar tujuan-tujuan yang hendak dicapai dapat terwujud secara optimal. Akan tetapi, jika melihat di dalam undang-undang, peraturan pemerintah, hingga keputusan-keputusan menteri yang membarengi Dana Desa tersebut, aspek perencanaan sedikit sekali dilibatkan, bahkan hampir nihil.

Sebagian besar dari peraturanperaturan yang dikeluarkan pemerintah tersebut hanya berisikan dasar pembagian Dana Desa, arahan penggunaan, tujuan, prioritas, dan prinsip-prinsip penggunaan Dana Desa. Padahal, sebagaimana diketahui bersama, pemerintah desa sebagai pelaksana program pemanfaatan Dana Desa tersebut juga memerlukan bekal-bekal ilmu perencanaan mengingat disadari atau tidak, mereka akan melakukan proses-proses perencanaan tersebut dalam menyusun programprogram pembangunan dari Dana Desa tersebut. Apalagi dalam prinsip penggunaan Dana Desa yang disebutkan pada Buku Pintar Dana Desa terbitan Kementerian Keuangan Republik Indonesia, terdapat penekanan pada swakelola masyarakat yang berarti pelaksanaannya dilakukan secara mandiri engan pemberdayaan sumberdaya alam desa, tenaga, pikiran, dan keterampilan warga desa, dan kearifan lokal, yang semuanya membutuhkan perencanaan yang matang agar dapat terlaksana dengan baik.

Penelitian-penelitian tentang Dana Desa yang mengkaji dari aspek perencanaan dirasa masih sangat terbatas. Sebagian besar masih berfokus pada 
akuntabilitas pengelolaan dan efektivitas pengelolaan yang ditinjau dari aspek ekonomi.

Meutia dan Liliana (2017) mengkaji tentang pengelolaan keuangan Dana Desa dengan studi kasus di Kabupaten Ogan Ilir, Sumatera Selatan. Dalam penelitian tersebut diketahui bahwa dalam pengelolaan keuangan secara umum, Dana Desa telah dilaksanakan sesuai dengan aturan Permendagri No. 113/2014 dan mematuhi prinsip dasar pengelolaan keuangan. Akan tetapi, masalah pelaporan dan pertangungjawaban masih menjadi masalah di beberapa desa sehingga mengakibatkan ketimpangan dalam pelaksanaan pembangunan.

Sementara itu, Aziz (2016) dalam penelitiannya tentang Otonomi Desa dan Efektivitas Dana Desa mendapati bahwa pelaksanaan penggunaan Dana Desa masih belum efektif lantaran belum memadainya kapasitas dan kapabilitas pemerintah desa. Selain itu, peran serta masyarakat secara aktif dalam pengelolaan Dana Desa juga belum terlihat.

Sofiyanto, Mardani, dan Salim (2017) pun pernah mengkaji tentang Dana Desa yang berfokus pada pengelolaan Dana Desa dalam upaya meningkatkan pembangunan di desa Banyuates, kecamatan Banyuates, kabupaten Sampang. Dari hasil penelitian tersebut diketahui bahwa pengelolaan Dana Desa secara teknis maupun administratif telah sesuai dengan peraturan yang ada dengan pemerintah desa cukup serius dalam mengelola Dana Desa untuk meningkatkan sarana, prasarana, dan sumberdaya manusia di desa tersebut. Alhasil, Dana Desa pun memberikan dampak positif terhadap pembangunan desa baik di bidang pembangunan fisik maupun pembangunan manusianya.

Berdasarkan kajian dari tiga jurnal di atas, menunjukkan bahwa kompetensi pengelola dan kepatuhan terhadap arahan-arahan atau peraturan-peraturan pemerintah yang berlaku menjadi hal yang sangat penting dalam pelaksanaan program pemanfaatan Dana Desa. Kendati demikian, sebagaimana yang dijelaskan sebelumnya, ketiganya belum menyentuh aspek perencanaan dalam kajian tentang Dana Desa.

Evaluasi-evaluasi terhadap program pemanfaatan Dana Desa sendiri sudah sering dilakukan, baik oleh pemerintah sendiri maupun para peneliti. Evaluasi dari pemerintah menunjukkan bahwa Dana Desa telah memberikan manfaat yang cukup besar bagi masyarakat. Dari Dana Desa ini, berbagai sarana dan prasarana publik desa telah terbangun, seperti jalan, jembatan, sambungan air, drainase/irigasi, pasar desa, polindes, PAUD, sumur, dan embung desar. Di sisi lain, Dana Desa juga telah meningkatkan Gini Rasio Desa dari 0,34 (2014) menjadi 0,32 (2017), menurunkan jumlah penduduk miskin dari 17,7 juta jiwa (2014) menjadi 17,1 jiwa (2017), menurunkan persentase penduduk miskin dari 14,09\% (2014) menjadi 13,93\% (2017), dan meningkatkan garis kemiskinan dari Rp286,1 ribu (2014) menjadi Rp361,5 ribu (2017).

Hal yang cukup menarik, evaluasi tersebut didapat dari penilaian manfaat Dana Desa secara keseluruhan dan masih belum menyorot keterkaitannya dengan pembangunan, apakah program hasil pemanfaatan Dana Desa itu sudah sesuai dengan perencanaan desa atau hanya sekadar mengikuti arahan pemerintah, meniru program dari desa lain, atau 
memang ada pertimbangan khusus yang melatarbelakangi program tersebut. Dan ketika ditelisik lebih dalam, tidak sedikit program-program yang dihasilkan dari Dana Desa ini pada kenyataannya belum berjalan dengan optimal dan kurang dapat dirasakan manfaatnya oleh warganya sendiri.

Beberapa desa mungkin telah berhasil menjalankan program Dana Desa ini, namun tidak sedikit pula desa yang berujung pada kegagalan dan justru menjadi lumbung korupsi baru bagi sejumlah aparat desa yang tidak bertanggung jawab. Ketua Departemen Luar Negeri Badan Pelaksana Pusat (BPP) Dewan Pengurus Pusat (DPP) Serikat Petani Indonesia (SPI), Zainal Arifin Fuad (2017), sebagaimana dilansir dalam www.kabarjitu.com bahkan mengemukakan kegagalan fatal program Dana Desa. Menurutnya, terdapat dua isu besar dalam pelaksanaan program Dana Desa yang perlu dibenahi. Pertama, terkait pendistribusian Dana Desa. Program Dana Desa dinilai terlalu fokus pada pembangunan infrastruktur yang secara sistematis tidak berimbas pada kesejahteraan masyarakat Indonesia dan justru dinikmati oleh sekelompok kecil masyarakat. Kedua, yakni pemerintah harus melihat pembangunan desa sebagai pembangunan yang menitikberatkan pada perlindungan khazanah lokal perdesaan mengingat selama ini masyarakat desa, khususnya petani, masih hidup dalam lingkup kegamanangan pemerintah desa dalam menggantungkan ekonomi petani dan mata rantai distribusi hasil panen petani kepada pihak lain sehingga manfaat Badan Usaha Milik Desa (BUMDes) belum dapat dirasakan langsung oleh petani dalam menjalankan usaha tani mereka. Jika dipahami lebih dalam, dua isu besar tersebut erat kaitannya dengan proses perencanaan pada penentuan program pemanfaatan Dana Desa.

Dari penjelasan-penjelasan di atas, dirasa perlu adanya tinjauan teori perencanaan dalam program pemanfaatan Dana Desa. Dengan mempertimbangkan pentingnya perencanaan dalam setiap program pembangunan, tinjauan terhadap teori perencanaan dirasa perlu untuk mengetahui apakah program-program pemanfaatan Dana Desa yang diselenggarakan pemerintah desa sudah sesuai dengan teori perencanaan atau belum.

Dalam penelitian ini, aspek yang dikaji meliputi enam tahap proses perencanaan yang kemudian digunakan sebagai variabel, yakni seperti yang diuraikan sebelumnya, meliputi diagnosis masalah, perumusan tujuan, proyeksi dan perkiraan, pengembangan alternatif, analisis kelayakan, dan evaluasi. Tahap implementasi tidak disertakan mengingat tahap tersebut sejatinya sudah masuk pelaksanaan rencana yang telah disusun. Dengan melakukan analisis melalui tujuh elemen tersebut diharapkan dapat diketahui kesesuaian program pemanfaatan Dana Desa terhadap teori perencanaan yang berlaku selama ini. Jika memang program pemanfaatan Dana Desa selama ini dilakukan tidak sesuai dengan teori perencanaan, bisa jadi hal tersebut menjadi salah satu faktor mengapa Dana Desa dirasa belum memberikan dampak efektif dalam pembangunan.

\section{METODE PENELITIAN}

Penelitian ini dilaksanakan di Desa Jatiroto, Kecamatan Kayen, Kabupaten Pati. Sebagian wilayah desa ini terletak di 
jalur yang menghubungkan Kabupaten Pati dengan Kabupaten Grobogan dan jalur penghubung Kecamatan Kayen dengan Kecamatan Tambakromo.

Pendekatan yang dilakukan pada penelitian ini adalah pendekatan deduktif yang bermula dari teori dan kajian pustaka dan kemudian dijadikan acuan dalam mengkaji obyek penelitian sehingga perlu dilakukan pengujian teori di lapangan dengan menggunakan variabel-variabel yang disusun berdasarkan teori. Adapaun metode analisisnya menggunakan metode deskriptif kualitatif yang disajikan melalui tulisan, gambar, maupun grafik atau tabel. Diharapkan dengan metode ini analisis yang dilakukan bisa lebih mendalam dan tidak terpaut pada angkaangka atau nilai-nilai kuantitatif saja. Dalam hal ini, pengujian teori dilakukan dengan membandingkan realisasi program pemanfaatan Dana Desa terhadap tahap-tahap proses perencanaan.

Teknik pengambilan sampel yang digunakan adalah snow-ball sampling. Teknik sampling ini memiliki konsep wawancara mendalam yang baru berhenti ketika tidak ada informasi baru lagi, terjadi replikasi, atau pengulangan variasi informasi, atau mengalami titik jenuh informasi.

Berdasarkan penjelasan mengenai sampling di atas, kepala desa Jatiroto, dengan inisial MEW, dipilih sebagai informan mengingat ia merupakan sosok yang paling memahami proses pelaksanaan program pemanfaatan Dana Desa, termasuk dalam tahap perencanaannya.

Metode Penelitian terdiri dari Rancangan Penelitian, Subjek penelitian, identifikasi variabel dan Instrumen Penelitian, dan Prosedur \& Analisa Data. Paparan metode ditulis dengan jelas agar dapat dipahami oleh pembaca.

Model analisis yang digunakan dalam penelitian ini adalah model analisis interaktif. Miles dan Huberman (1992) mengemukakan bahwa analisis interaktif merupakan model penelitian yang memiliki empat komponen analisis, meliputi pengumpulan data, reduksi data, penyajian data, dan penarikan kesimpulan.

Setelah pengumpulan data, diperlukan adanya reduksi data sehingga dapat memberikan gambaran lebih jelas dan bisa mempermudah peneliti untuk mengumpulkan data selanjutnya. Agar tidak keluar dari konteks, peneliti berpegang pada tujuan penelitian yang ingin dicapai. Penyajian data dalam penelitian kualitatif dilakukan dalam bentuk uraian singkat, bagan, hubungan antar kategori, flowchart, dan sejenisnya. Selanjutnya, dilakukan penarikan kesimpulan dan verifikasi untuk menjawab pertanyaan penelitian.

\section{HASIL DAN PEMBAHASAN}

Hasil dari penelitian ini berupa uraian wawancara dari informan MEW, yang dilakukan pada 23 Agustus 2018 lalu. Berdasarkan hasil tersebut, penelita melakukan analisis dengan berpegang pada aspek enam tahap perencanaan yang berfungsi sebagai variabel.

Sejak diluncurkan pada 2015 silam hingga pertengahan 2018 ini, Dana Desa di Desa Jatiroto, Kecamatan Kayen, Kabupaten Pati telah menghasilkan sejumlah produk pembangunan, berupa jalan desa, talud jalan, jalan pertanian, 
kios, revitalisasi lapangan voli, dan penyertaan modal untuk BUMDes. Produk tersebut selain arahan dari pemerintah pusat juga amanat RPJMDes yang disusun oleh pemerintah desa untuk periode 2015 hingga 2021.

Pembangunan yang baik seyogyanya diawali dengan proses perencanaan. Sebagaimana disebutkan dalam pendahuluan, terdapat enam proses perencanaan, yakni diagnosis masalah, perumusan tujuan, proyeksi dan perkiraan, pengembangan alternatif, analisis kelayakan, dan evaluasi. Berikut ini adalah hasil penilaian terhadap ketujuh variabel tersebut dalam pelaksanaan program pemanfaatan Dana Desa di Desa Jatiroto.

\section{Diagnosis Masalah}

Perencanaan didasari karena adanya ketidakpuasan terhadap kondisi yang ada berupa isu-isu yang berkembang atau sengaja dikembangkan. Berdasarkan pengamatan di lapangan, dari enam produk hasil pembangunan, hanya talud jalan, jalan perttanian, dan kios desa yang berakar dari masalah yang terjadi di desa. Hal tersebut sejalan dengan pernyataan kepala desa dalam petikan wawancara berikut.

“... Dari pemerintah Dana Desa memang difokuskan untuk pembangunan infrastruktur desa, khususnya jalan, makanya di sini harapannya semua jalan nanti dirabat beton. Tetapi, sebagian juga disusun dari permasalahan yang terjadi di desa. Contohnya, talud jalan dibangun karena di desa sering banjir dan tergenang saat hujan deras. Jalan pertanian juga kita bangun karena selama ini jalannya masih berupa tanah, kasihan para petani, kendaraan juga susah masuk sawah.
Kalau lapangan voli desa dituntut untuk memiliki sarana olahraga. Sedangkan kios desa ini kami melihat arah perkembangan Kecamatan Kayen ke timur, kita ada lahan di situ, ya kita manfaatkan. Sementara BUMDes ini kita punya persewaan alat-alat bangunan, selain kita gunakan sendiri untuk membangun jalan dan talud, juga bisa kita sewakan ke desa lain atau warga yang membutuhkan."

\section{Perumusan Tujuan}

Perumusan tujuan sejatinya erat kaitannya dengan permasalahan. Jika masalah didefinisikan dengan jelas, maka tujuan perencanaan akan jelas mengingat pada dasarnya tujuan dimaksudkan untuk menjawab permasalahan. Terkait tujuan program pemanfaatan Dana Desa, berikut ini adalah petikan wawancara dengan kepala desa.

“...dengan adanya Dana Desa ini diharapkan nanti semua jalan desa bisa dilapis rabat beton dan di kanankirinya ada taludnya, jalan-jalan pertanian juga bagus. Kios desa dan BUMDes harapannya bisa menambah pendapatan desa."

Berdasarkan pernyataan tersebut, kata 'diharapkan' menjadi petunjuk bahwa program pemanfaatan Dana Desa di Jatiroto memiliki tujuan yang telah dirumuskan sebelumnya. Akan tetapi, dari hal tersebut, didukung pengamatan langsung di lapangan, perumusan tujuan masih condong pada tujuan proyek, yakni sebatas kegiatan tersebut selesai tepat waktu, dan belum menyentuh tujuan besar yang hendak dicapai dari program tersebut, yang memberikan pengaruh langsung pada kehidupan masyarakat. Sementara itu, dari kajian RPJMDes juga 
tidak tercantum tujuan program-program yang disusun secara jelas.

\section{Proyeksi dan Perkiraan}

Perencanaan sejatinya sangat menekankan orientasi pada masa depan sehingga aspek prediksi ini menjadi hal penting di dalam prosesnya. Dalam pelaksanaan program pemanfaatan Dana Desa di desa Jatiroto, tahap ini dilakukan untuk menyusun langkah antisipasi jika terbentur masalah, terutama hak milik dengan warga setempat, sebagaimana pernyataan kepala desa berikut.

"Untuk masalah biasanya kalau nabrak tanah warga, kita upayakan langkah biasanya dengan negosiasi, kita bicarakan baik-baik dan kita beri pemahaman. Kalau lapangan voli sengaja dipilih tanah milik desa, supaya nanti tidak ada masalah ke depannya."

Dari pernyataan tersebut dan pengamatan di lapangan, tahap proyeksi dan perkiraan belum sepenuhnya dilakukan mengingat dari wawancara informan tersebut, hanya dibahas mengenai peluang konflik di masa depan.

\section{Pengembangan Alternatif}

Dalam proses perencanaan, pengembangan alternatif menjadi salah satu yang kerap diabaikan. Padahal, tahap ini dapat memberi pengaruh yang signifikan terhadap kualitas keputusan akhir, mengingat keputusan tersebut berasal dari rangkaian pilihan yang akan dipilih dalam rencana. Pun yang terjadi di desa Jatiroto terkait program pemanfaatan Dana Desa ini. Dari pengamatan langsung di lapangan dan studi baik dari dokumen RPJMDes, RKP Desa, maupun petunjuk teknis dan petunjuk pelaksanaan program Dana
Desa, tidak ditemukan adanya tahap pengembangan alternatif tersebut.

\section{Analisis Kelayakan}

Analisis kelayakan dilakukan dengan mengajukan pertanyaan terhadap setiap pilihan, terutama terkait hambatanhambatan yang mungkin muncul, termasuk hambatan-hambatan kurang nyata seperti hambatan politis atau kelembagaan. Sama halnya dengan pengembangan alternatif, dari pengamatan langsung di lapangan dan studi baik dari dokumen RPJMDes, RKP Desa, maupun petunjuk teknis dan petunjuk pelaksanaan program Dana Desa, tidak ditemukan adanya tahap ini.

\section{Evaluasi}

Tahap evaluasi dijalankan ketika perencana telah mengantongi sejumlah alternatif. Kriteria umum yang kerap digunakan adalah efisiensi dengan memilih alternatif mana yang memberikan hasil terbanyak dengan biaya sama. Dari pengamatan langsung di lapangan dan studi baik dari dokumen RPJMDes, RKP Desa, maupun petunjuk teknis dan petunjuk pelaksanaan program Dana Desa, tahap ini ternyata tidak dilakukan dalam program pemanfaatan Dana Desa. Evaluasi hanya dilakukan ketika kegiatan selesai dilaksanakan untuk melihat kualitasnya. Berikut adalah petikan wawancara dengan kepala desa.

"Setelah kegiatan selesai biasanya kita cek, hasilnya seperti apa, kualitasnya seperti apa, kalau ada yang kurang baik nanti kita perbaiki."

Dari uraian di atas, diketahui bahwa program-program pemanfaatan Dana Desa tidak didahului dengan proses perencanaan yang sesuai dengan teori. 
Hal yang membuat proses perencanaan program-program pemanfaatan Dana Desa di Jatiroto memprihatinkan adalah tidak dilakukannya tahap pengembangan alternatif, analisis kelayakan, dan evaluasi sehingga program-program tersebut seolah dipaksa harus dijalankan tanpa adanya fleksibilitas terhadap pilihan-pilihan lain ataupun perubahan yang mungkin terjadi.

\section{SIMPULAN}

Terhitung sejak tahun 2015 hingga 2018, desa Jatiroto telah menghasilkan enam produk pembangunan dari program pemanfaatan Dana Desa, yakni jalan desa, talud jalan, jalan pertanian, revitalisasi lapangan voli, pembangunan kios desa, dan penyertaan modal BUMDes. Berdasarkan hasil dan pembahasan sebelumnya, ternyata program-program yang dijalankan tersebut tidak sesuai teori perencanaan secara umum, dengan diagnosis masalah dan perumusan tujuan tidak terlaksana secara sempurna, sementara proyeksi dan perkiraan, pengembangan alternatif, analisis kelayakan, dan evaluasi tidak dilakukan.

Perencanaan sendiri sangat penting dalam menentukan keberhasilan pembangunan sehingga seyogyanya setiap program pembangunan yang dilakukan, termasuk dari pemanfaatan Dana Desa ini memberi perhatian lebih pada aspek perencanaan. Dengan demikian, diharapkan program-program yang dijalankan dapat lebih tepat sasaran dan memberi peluang keberhasilan yang lebih tinggi pula.

\section{DAFTAR PUSTAKA}

Aziz, Nyimas Latifah Letty. (2016). Otonomi Desa dan Efektivitas Dana Desa. Jurnal Penelitian Politik. 13(2). 193-211.

Bahl, R. (1999). Implementation Rules for Fiscal Decentralization. Working Paper No. 10. Atlanta, Georgia: International Studies Program, School of Policy Studies, Georgia State University.

Bryant, Coraile dan Louise G. Whiter. (1982). Managing Development in the Third Wolrd. Boulder, CO: Westview Press.

Helling, Louis,Serrano, R,Warren,David. (2005). Lingking Community Empowerment, Decentralized Governance and Public Service Provision though a local Development Framework. Social Protection Discussion Paper 0535. World Bank Washington DC.

Kementrian Keuangan Republik Indonesia. (2014). Buku Pintar Dana Desa keluaran Kementerian Keuangan Republik Indonesia. Jakarta: Kemenkeu RI.

Lembaga Administrasi Negara (LAN) dan Deutsche Stiftung Fur Internationale Entwicklung (DSE). (1999). Modul Diklat Perencanaan Pembangunan Wilayah. Jakarta: LAN RI.

Mahi, Ali Kabul, Trigunarso, Sri Indra. (2017). Perencanaan Pembangunan Daerah: Teori \& Aplikasi . Jakarta: Kencana Prenada Media Group.

Miles, Hubermen. (1992). Analisis Data Kualitatif. Jakarta: Universitas Indonesia.

Meutia, Inten dan Liliana. (2017). Pengelolaan Keuangan Dana Desa. Jurnal: Akuntansi MultipAragidgma. 8(2). 336-352. 
Republik Indonesia. (2014). Peraturan Pemerintah Nomor 60 Tahun 2014 tentang Dana Desa. Jakarta: Sekretariat Negara.

Republik Indonesia. (2017). Peraturan Menteri Desa, Pembangunan Daerah Tertinggal, dan Transmigrasi Republik Indonesia Nomor 19 Tahun 2017 tentang Penetapan Prioritas Penggunaan Dana Desa Tahun 2018. Jakarta: Sekretariat Negara.

Republik Indonesia. (2014). Undang-Undang Nomor 6 Tahun 2014 tentang Desa. Jakarta: Sekretariat Negara.

Sofiyanto, Moh., Ronny Malavia Marani, dan M. Agus Salim. (2017). Pengelolaan Dana Desa dalam Upaya Meningkatkan Pembangunan di Desa Banuates Kecamatan Banyuates Kabupaten Sampang. E-Jurnal Riset Manajemen Prodi Manajemen Fakultas Ekonomi Unisma. 1(1). (28-38).

Syarif. (2017). Kegagalan Fatal Program Dana Desa. Diterima 18 Mei 2018, dari http://kabarjitu.com/2017/12/kegagalan-fatal-program-dana-desa/.

Turner, M. \& Hulme, D. (1997). Governance, Administration, and Development: Making The State Work. Houndmills: Macmillan. 